Jpn. J. Phys. Fitness Sports Med. 2006, $55: 429 \sim 432$

\title{
【Short Communication】
}

\section{EFFECTS OF KNEE EXTENSOR MUSCLE GROUP FATIGUE ON LOWER LIMB JOINTS TORQUES DURING JUMPING}

\author{
Mitsugi OGATA ${ }^{1)}$, KAZUShi Shimada ${ }^{2)}$, YOSHIAKI MANABE ${ }^{3)}$,

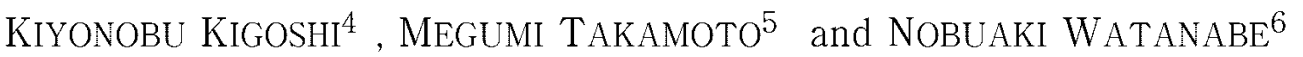

key words : Muscle fatigue, Jump exercise, Recovery, Torque

\section{I . Objective}

Muscle fatigue reduces sport performance, and fatigue tolerance is thought to be affected by muscle endurance. Ogata et al. ${ }^{1)}$ reported that speed reduction during $400 \mathrm{~m}$ racing, which has a significant correlation to the $400 \mathrm{~m}$ goal time, is affected by endurance of hip extension and flexion movements. This suggests that muscle fatigue changes joint torque during sprinting and modifies running motions ${ }^{2,3)}$. In addition, modifying running motions may suppress performance reduction through compensatory use of non-fatigued areas.

Whether synergistic muscles compensate if agonist fatigue reduces power is an interesting topic of study. Relationship between fatigue and performance have not previously been investigated in terms of jumping (consecutive 1-leg jumping). In the present study, the quadriceps femoris, an agonist, was fatigued before testing, and changes in the power expression of lower limb joints during jumping were ascertained.

\section{Methods}

\section{A. Subjects}

Subjects were 7 male track-and-field athletes who were skilled at jumping. Mean age, height and body weight of subjects were $21.5 \pm 0.8$ years, $176.2 \pm 5.6$ $\mathrm{cm}$ and $71.3 \pm 5.8 \mathrm{~kg}$, respectively. Consent to participate in the present study was obtained after explaining the study objective and potential pain associated with the test.

\section{B. Test procedures}

A serial test was performed to ascertain effects of knee extensor muscle group fatigue on consecutive 1-leg jumping. The test was composed of the following 3 stages : 1) after a warm-up, each non-fatigued subject was instructed to jump on 1 leg 5 times on a force platform(Kistler : 9281type); 2) using an isokinetic muscular strength analyzer (Lumex : Cybex6000), each subject was asked to extend the knee at full strength 30 times at an angular velocity of $180^{\circ} / \mathrm{s}$ and then relax until return the leg to the original position consecutively. This trial was de-

\footnotetext{
1) 筑波大学人間総合科学研究科 干 305-8574 茨城県つくば市天王台 $1-1-1$

2) 茨城県立医療大学 干300-0394 茨城県稲敷郡阿見町阿見4669-2

3) 国際武道大学体育学部 干299-5295 千葉県勝浦市新官299

4) 愛知教育大学教育学部 干448-8542 愛知県刚谷市井ヶ谷町広沢 1

$5)$ 大阪体育大学体育学部 干590-0496 大阪府泉南郡熊取町朝代台 1-1

6) 山形県立米沢女子短期大学 干992-0025 山形県米沢市通町6-15-1

Graduate School of Comprehensive Human Sciences, University of Tsukuba 1-1-1 Tennodai, Tsukuba, Ibaraki, 305-8574 Ibaraki Prefectural University of Health Sciences, 4669-2 Ami, Ami, Inashiki, Ibaraki, 300-0394

Faculty of Physical Education, International Budo University 841 Shinkan, Katsuura, Chiba, 299-5295 Aichi University of Education, Faculty of Education, 1 Hirosawa, Igaya, Kariya, Aich, 448-8542 Osaka University of Health and Sports Sciences 1-1 Asashirodai, Kumatori, Senan, Osaka 590-0496 Yonezawa Women's College of Yamagata Prefecture 6-15-1 Tohorimachi, Yonezawa, Yamagata, 992-0025
} 
fined as the fatigue exercise. Mean peak torques were calculated for the first 15 and the last 15 repetitions. Muscle endurance index was calculated by dividing the second-half mean by the first-half mean and multiplying by $100(\%)$; and 3 ) each subject was instructed to jump on 1 leg 5 times at 1, 3 and 5 min after the end of the fatigue exercise. Jumping movements were analyzed using an optic 3-dimensional position analysis system (Oxford Metric: BICON) at a sampling rate of $120 \mathrm{~Hz}$. At the same time, ground reaction force was measured at a sample rate of $1000 \mathrm{~Hz}$. Air time of the 5 consecutive jumps was calculated based on ground reaction force data, and the highest jump was selected for motion analysis. Based on ground reaction force and video analyzed data, torques for the three lower limb joints were calculated. Also, in relation to the lowest point of the center of gravity during jumping, the downward phase was defined as the eccentric phase, while the upward phase was defined as the concentric phase.

\section{Statistical analysis}

Rate of change in jump height and joint torque was calculated for 1, 3 and 5 min after fatigue exercise using equation ( 1 ) below :

Rate of change $=($ value before fatigue exercise

- value after fatigue exercise)/value before

$$
\text { fatigue exercise } \times 100 \text { (\%) }
$$

Paired one-way analysis of variance (ANOVA) was used to analyze significance of jump height and torques of the 3 lower limb joints before and 1, 3 and $5 \mathrm{~min}$ after fatigue exercise, and a multiple com- parison test was used to further analyze items with significant $F$ values. To ascertain relationships among investigated items, Pearson's correlation coefficients were calculated. Values of $p<0.05$ were considered statistically significant.

\section{Results}

Muscle endurance index calculated in this study was $78.7 \pm 6.3 \%$ (Mean \pm S. D. )

Table 1 shows mean torques of the hip, knee and ankle joints in the eccentric and concentric phases and jump height before and 1, 3 and 5 min after fatigue exercise. Jump height was significantly lower at 1 and $3 \mathrm{~min}$ after fatigue exercise than before fatigue exercise. Jump heights were significantly higher at 3 and 5 min than at 1 min after fatigue exercise. Significant changes in joint torque were seen for the hip and knee joints. Hip joint torque was significantly higher in the concentric phase at 5 min after fatigue exercise compared to before fatigue exercise. Compared to before fatigue exercise, knee joint torques in the eccentric and concentric phases at 1,3 and 5 min after fatigue exercise were significantly lower.

Figure 1 shows the relationships between rate of change in the knee joint torque and jump height at 1 , 3 and $5 \mathrm{~min}$ after fatigue exercise. Only at $1 \mathrm{~min}$ after fatigue exercise, significant correlations were identified between rate of change in jump height and rate of change in torque in the eccentric phase $(p<$ $0.05)$ and concentric phase $(p<0.01)$.

Table 1. Jump height and lower limbs joint torques before and 1, 3 and 5 min after fatigue exercise.

\begin{tabular}{|c|c|c|c|c|c|c|c|}
\hline & /ariable & pre & $1 \mathrm{~min}$ & $3 \mathrm{~min}$ & $5 \mathrm{~min}$ & $\begin{array}{l}\text { Variance } \\
\text { analysis }\end{array}$ & multiple comparison \\
\hline Jump hei & ight $(\mathrm{m})$ & $0.267 \pm 0.036$ & $0.201 \pm 0.026$ & $0.240 \pm 0.034$ & $0.246 \pm 0.044$ & & Pre $>3 \min >1 \mathrm{~min}, 1 \mathrm{~min}<3 \cdot 5 \mathrm{~min}$ \\
\hline \multicolumn{8}{|c|}{ Joint torque/Body weight $(\mathrm{Nm} / \mathrm{kg})$} \\
\hline \multirow[t]{2}{*}{ Hip } & Eccentric & $2.50 \pm 0.57$ & $2.66 \pm 1.23$ & $2.74 \pm 1.33$ & $3.19 \pm 0.84$ & * & pre $<5$ min \\
\hline & Concentric & $1.59 \pm 0.16$ & $1.61 \pm 0.74$ & $1.63 \pm 0.90$ & $1.97 \pm 0.68$ & & \\
\hline \multirow[t]{2}{*}{ Knee } & Eccentric & $1.85 \pm 0.39$ & $1.10 \pm 0.22$ & $1.23 \pm 0.48$ & $1.37 \pm 0.32$ & $* * *$ & Pre $>1 \mathrm{~min} \cdot 3 \mathrm{~min} \cdot 5 \mathrm{~min}$ \\
\hline & Concentric & $1.75 \pm 0.52$ & $1.16 \pm 0.49$ & $1.06 \pm 0.48$ & $0.88 \pm 0.46$ & $* * *$ & Pre $>1 \mathrm{~min} \cdot 3 \mathrm{~min} \cdot 5 \mathrm{~min}$ \\
\hline \multirow[t]{2}{*}{ Ankle } & Eccentric & $3.24 \pm 0.44$ & $2.94 \pm 0.58$ & $3.27 \pm 0.36$ & $3.35 \pm 0.38$ & & \\
\hline & Concentric & $3.37 \pm 0.87$ & $2.94 \pm 0.27$ & $2.96 \pm 0.21$ & $3.04 \pm 0.39$ & & \\
\hline
\end{tabular}

$* * *: p<0.001, *: p<0.05,<>: p<0.05$ 

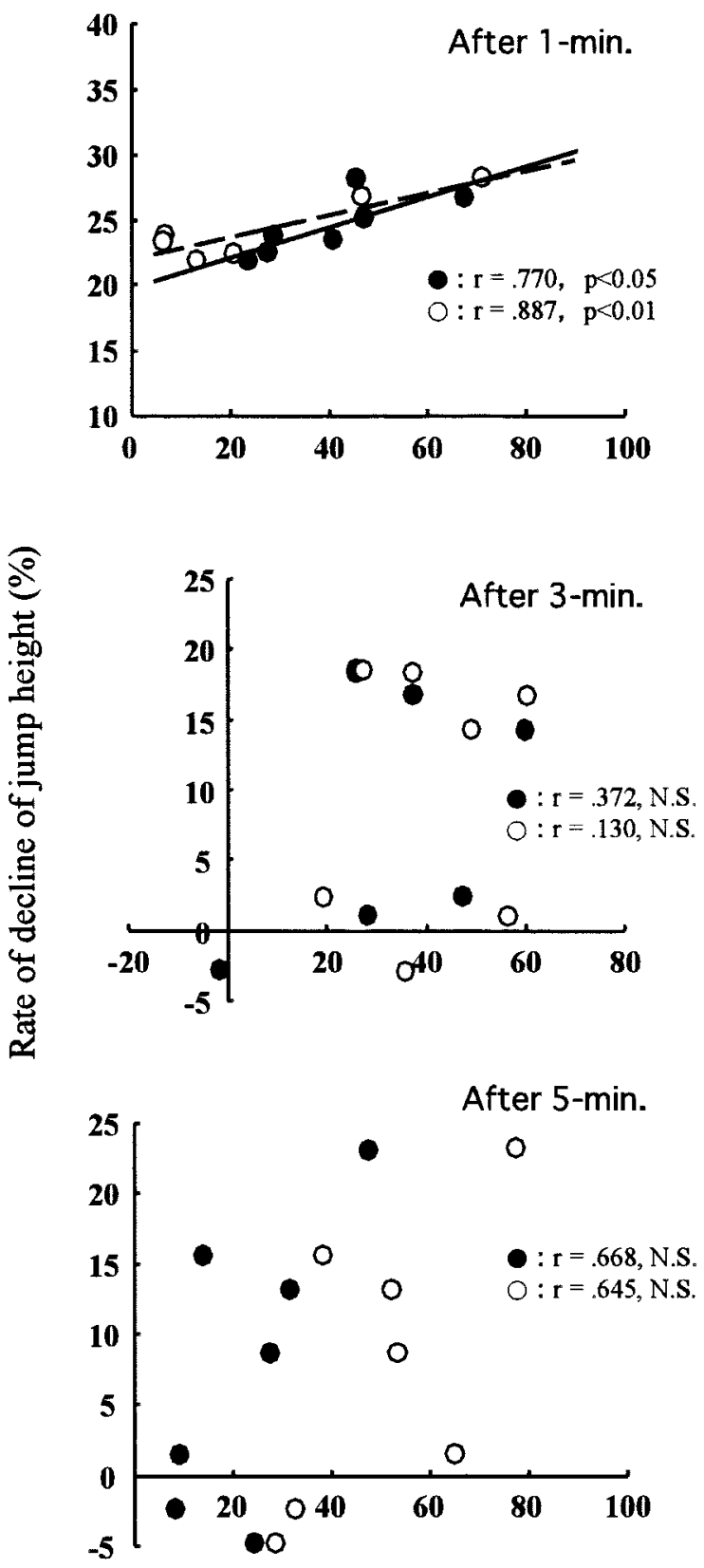

\section{Rate of decline of knee joint torque (\%)}

eccentric $O$ concentric

Fig. 1. Relationships between rate of decline of knee joint torques and jump height.

\section{Discussion}

Knee joint torques were significantly lower in eccentric and concentric phases at 1, 3 and $5 \mathrm{~min}$ after fatigue exercise than before exercise, suggesting that muscle fatigue did not recover within 5 min and torque expression during jumping remained low.
The greater the rate of change in knee joint torque 1 min after fatigue exercise, the greater the rate of change in jump height, suggesting that fatiguing the knee extensor muscle group, the agonist for jumping, reduces knee extension torque during jumping and lowers jump height (Fig. 1).

Although knee joint torque remained significantly low at 3 and 5 min after fatigue exercise, no significant relationships were noted between rate of change in torque and rate of change in jump height. This is because at 3 min after fatigue exercise, reduced knee joint torque was somehow compensated for by the other 2 joints.

At 5 min after fatigue exercise, no significant changes in jump height were noted and values were almost recovered to pre-fatigue levels. However, knee joint torque in the eccentric and concentric phases remained significantly low. Hip joint torque in the eccentric phase was significantly greater, and this change appears to have contributed to recovery of jump height. The 3 lower limb joints perform different roles during jumping, but all 3 joints affect each other through kinetic chains ${ }^{4,5)}$ and inter-joint energy flow ${ }^{6,7)}$. Kigoshi et al. ${ }^{1}$ reported that hip extension power of the downward phase in drop jump grounding affects ankle joint torque in the subsequent upward phase through power transmission of the biarticular muscles. In the present study, no significant increases were seen in ankle joint torque, and increases in hip joint torque could have somehow affected the function of the other two joints to recover jumping power. In this manner, compensatory increases in hip-joint torque at 5 min after fatigue exercise were due to the feedback mechanisms compensating for fatigued muscles by recruiting other muscles.

\section{N. Conclusions}

The present results indicate that even when the knee extensor muscle group, the agonist for jumping, is fatigued and knee extension torque during jumping has not recovered, compensatory torque from the hip joint increases jumping power. 


\section{References}

1) Kigoshi, K., Iwai, K., Shimada, K. \& Ogata, M., Effects of the posture on the lower joints kinetics and the jump performance during the drop jump. Japan J. Phys. Educ. Hlth. Sport Sci.,(2004), 49, 435-445.

2) Ogata, M., Fukushima, H., Ohyama, K., Yasui, T., Nabekura, K., Miyashita, K., Sekioka, Y. \& Nagai, J., Relationships between muscular endurance of lower limbs and decrease in running speed during $400 \mathrm{~m}$ running. Japan J. Phys. Educ. Hlth. Sport Sci.,( 1998), 42, $370-379$.

3) Ogata, M., Manabe, Y. \& Takamoto, M., Relationship between physical fitness factors and the ability to maintain joint lower limb torques during the latter half of a 400 meter running event. J. Human Movement Studies, (2005), 48, 379-391.

4) Yasui, T., Aoyama, K., Ogata, M., Sekioka, Y., Nagai,
J., Miyashita, K., Fukushima, H. \& Ogiso, K., The study on differences between the first half and the second half in $400 \mathrm{~m}$ sprint. Research Quarterly for Athletic,(1998), 32, 15-24.

5) Putnam, C. A., A segment interaction analysis of proximal-to-distal sequential segment motion patterns. Med. Sci. Sports Exerc.,(1991), 23 : 130-144.

6) Putnam, C. A., Sequential motions of body segments in striking and throwing skills: descriptions and explanations. J. Biomech.,(1993), $26:$ 125-134.

7) Gregoire, L., Veeger, H. E. Huijing, P. A. \& Ingen Schenau., G. J. Van, Role of mono and biarticular muscles in explosive movements. Int. J. Sports Med., (1984), 5 : 301-305.

8) Bobbert, M. F. \& Ingen Schenau, G. J. Van., Coordination of vertical jumping. J. Biomech.,(1988), 21 : 241262 . 